\title{
Historein
}

Vol 14, No 1 (2014)

On the Edge of History and Philosophy

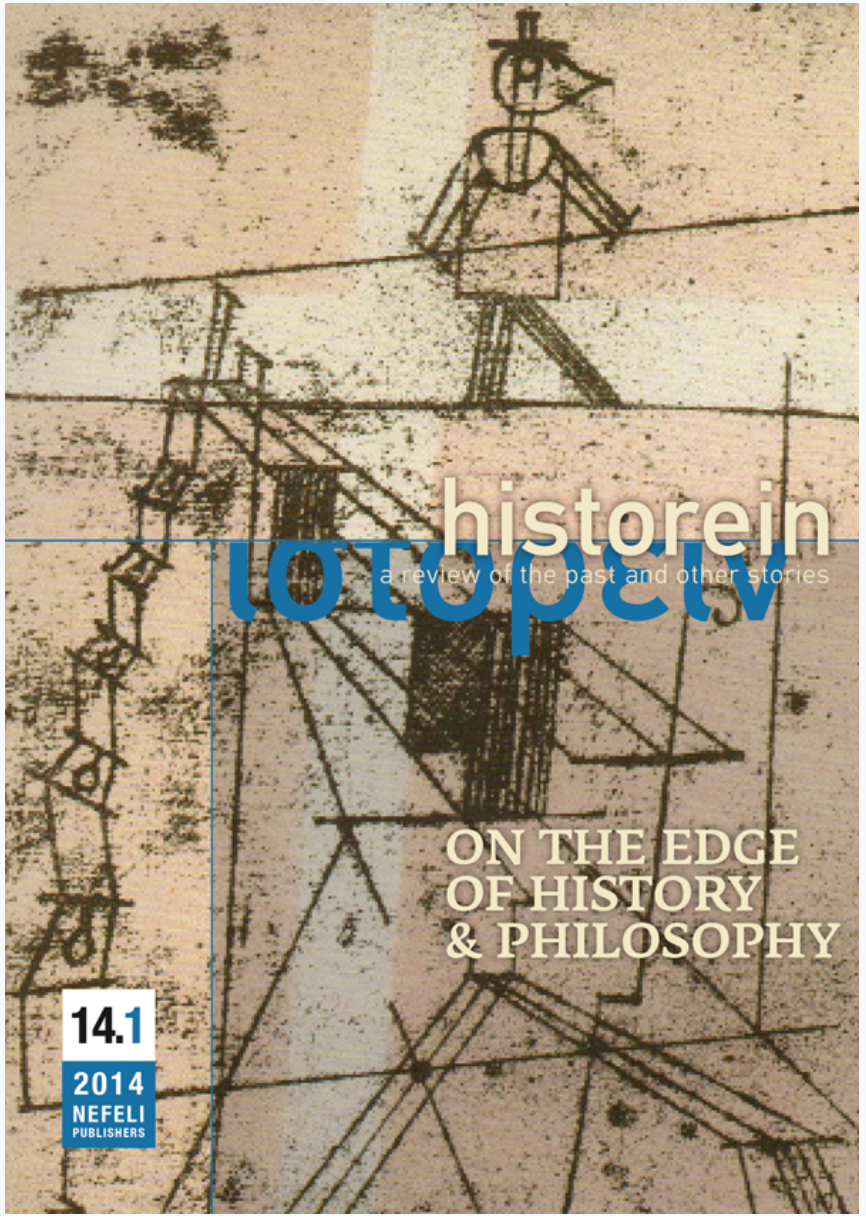

\section{Illuminating affects: Sexual violence as a crime against humanity. The Argentine case}

Cecilia Macon

doi: $10.12681 /$ historein.251

Copyright (@ 2014, Cecilia Macon

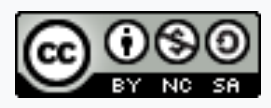

This work is licensed under a Creative Commons Attribution-NonCommercialShareAlike 4.0.

\section{To cite this article:}

Macon, C. (2013). Illuminating affects: Sexual violence as a crime against humanity. The Argentine case. Historein, 14(1), 22-42. https://doi.org/10.12681/historein.251 


\section{Illuminating affects: Sexual violence as}

a crime against humanity. The Argentine case
"Asesinas, terroristas, putas!"

["Murderers, terrorists, whores!"]

Victimhood as agency ${ }^{2}$ (and vice versa)

On 4 October 2011, Silvia Labairú gave testimony of having been raped and tortured while pregnant at ESMA, the biggest Argentine illegal detention centre: "They made me take off my clothes, shackled me, in front of the officers ... They beat me on a mat, asking for information". ${ }^{3}$ In July 2011, SAN, testifying at the trial for crimes committed at the Villa Urquiza jail in Tucumán, told her story: "Two men entered the room, one took off his shirt, got completely naked and ordered the other to touch me while the first raped my ass, (and) had his dogs bite me whenever I refused to kiss him". ${ }^{4}$ Like Silvia Labairú and SAN, hundreds of women have exposed their suffering of the sexual violence ${ }^{5}$ they experienced as females who were disappeared during the last Argentine dictatorship. The reasons why they finally decided to testify about these crimes are beyond our scope. However, what has captured our attention is the way in which these women affectively refer to their experiences of giving testimony. It is the status of their metatestimonies ${ }^{6}$ that is relevant for the present analysis. I believe that elucidating the main characteristics of these voices within the framework of the so-called "affective turn"7 - which defies some premises of traditional feminism to establish its starting point in queer theory - is fruitful in discussing the qualities of the tension between agency and victimhood beyond any established dichotomy. Indeed, it also helps to scrutinise a framework that challenges the essentialisation of the wound and certain disempowering consequences of the use of the concept of trauma, together with an inquiry into 
alternative ways of establishing contact with the injured past. However, it is important to note that this paper is not based on the allegation that affects define a naturally empowering dimension, but rather on the conviction that such a perspective is useful in order to defy certain established conceptual frameworks. ${ }^{8}$

Actually, the concept of "victimisation" has been analysed within the framework of gender theories - and of political theory, generally speaking - in radical opposition to that of agency: the passiveness of the injury vis-à-vis the power of action. The injured identity on which identity policies and the construction of collective action for sexual minorities are based implies a certain disdain for the transformative capabilities of victims and a submission to essentialism. Moreover, I consider that this process of essentialisation is a result of the same establishment of the dichotomy I plan to challenge. The concept of "victimisation" refers to the way in which, paradoxically, gender identity - most particularly, related to feminism - has been elaborated from the woman-as-victim quality. ${ }^{9}$ In other words, the envisioned emancipation seemed to be aimed at erasing the basis for collective identity it intended to defend. The "states of injury" and the "wounded attachments" refer to an original trauma linked to Nietzschean resentment, which should be put aside to embrace a truly empowering policy ${ }^{10}$ without erasing the existence of victimhood as a political category. It is our view that the testimonies given in the context of human rights trials by women who were victims of sexual violence offer the possibility of challenging such a dichotomy; in particular, from the acknowledgment of these crimes as crimes against humanity themselves. Contrary to some observations that sustain that these testimonies victimise women twice by having them re-enact their trauma, thus locating them in a sort of renovated rape, victims themselves have indicated that for them it was a liberating experience, not because of the mere fact of their recollection of the crimes, but because they are doing so within an environment deeply permeated by a gender perspective, an environment that was not present at the time of the junta trials of $1985 .{ }^{11}$ In fact, many statements from the state prosecutors have reflected this perspective, explicitly introduced by the "Considerations on the trials regarding sexual abuses committed in the context of state terrorism", in written advice from the attorney general's office to prosecutors in 2012 . The victims, by asserting that their public recollection of the horrors experienced has empowered them in some ways, questioned the dichotomy of victimhood/agency itself. In our understanding, this is possible because testimonies are blatantly expressed under the scope of affects, challenging - and reconstructing - the rules that govern the trials. The way affects - even the ones considered negative or "ugly"12 - are present in the victims' words, bodies and rhetorics and in their own assessment of their giving testimony opens up the possibility of redefining agency. I then refer to a level where affects permeate the recollection of the crimes, and where such affects are presented beyond the dichotomy of passion/action. As it has been stated by Hardt, affects can be both actions, as determined by internal causes, and passions, as determined by external causes. ${ }^{13}$ Such a perspective makes us reconsider not only the category of trauma - quite relevant for this matter - but also the impact that these recollections have on the public realm. Victimisation implies the labelling of an identity from a traumatic experience. Its alleged opposite, agency, seems to be imbued by the per- 
spective where the possible trauma had been subjected to mourning which secured agency definitively. In this case, there is a possibility to recollect traumatic experiences throughout an affective dimension, which indeed allows agency while not essentialising victimhood. From this perspective, the victim/agency dichotomy is definitively left behind, a question that is key to any gender theory.

Our main aim then is to analyse the metatestimonies given by victims of sexual violence within the context of crimes against humanity perpetrated during the last Argentine dictatorship, in order to show the limitations of the traditional dichotomic model and the fruitfulness of the affective turn regarding this matter. It should also be recalled that the idea of agency itself is essential to sustain emancipating processes such as those mentioned by gender theories in their different versions. A preliminary definition of agency now becomes relevant. In an attempt to introduce a general and standard characterisation, it can be stated that agency implies a capability to act. To achieve this, the agent should not only manage to start the action but also exert its power to do it. It also involves the capacity to challenge external authority to restate its own authority about how to act in relation to itself. I take a central element as a starting point for our definition of agency: its capacity to transform the meaning where the relation between meaning and experience becomes essential.

To define the concept of victim, I base my characterisation on the debates deployed around the now classical critical approach developed by Wendy Brown. Her analysis seeks to point out a very important issue: the fetichisation of the wound in subaltern politics. ${ }^{14}$ She wrote:

what kind of political recognition can identity-based claims seek ... that will not resubordinate a subject itself historically subjugated through identity, through categories such as race or gender that emerged and circulated as terms of power to enact subordination? ... what are the logics of pain in the subject formation processes of late modern polities that might contain or subvert the aim of achieving emancipatory political recognition? ${ }^{15}$

The reactions to injury are then inadequate as a basis of politics since such reactions make action impossible; thus making the transformation of the wound into an identity problematic. ${ }^{16}$ As Ahmed has stated, it is not a matter of forgetting the wound

or indeed the past as the scene of wounding ... forgetting would be a repetition of the violence or injury ... Our task might be instead to "remember" how the surfaces of bodies ... came to be wounded. Reading testimonies of injury involves rethinking the relation between the present and the past: an emphasis on the past does not necessarily mean a conservation or entrenchment of the past ... In order to break the seal of the past, in order to move away from attachments that are hurtful, we must first bring them into the realm of political action. ${ }^{17}$

Therefore, we are obliged to question the dichotomy between agency and victimhood present - I believe - in traditional conceptions both of agency and victimhood. In this respect, the role played by affects in the metatestimonies analysed here is particularly relevant. 


\section{Argentina: 1985 vs. 2010}

Before deploying our analysis of the metatestimonies and the framework that will help us to scrutinise its consequences, let's first summarise some milestones in recent Argentine history for those who are not familiar with it. On the dawn of 24 March 1976, Argentina suffered its sixth coup d'état, which resulted in the bloodiest dictatorship ever suffered by the country. In 1983, after free elections, Raúl Alfonsín - who belonged to the progressive wing of the centrist Radical Civic Union - became the first democratic president of the current era. Keeping with his campaign promises, Alfonsín made a historical decision: under the conviction that Argentine democracy needed new legitimising principles, only three days after coming to power he sent for trial the members of the juntas that governed Argentina for almost eight years. Between April and September 1985 thousands of testimonies were exposed to public scrutiny. Later, five members of the juntas - including two former presidents - were convicted and handed heavy sentences. However, the three coups d'état attempts that Alfonsín faced between 1987 and 1988 forced him to issue the so-called impunity laws - the full stop law that precluded any new trials after a set date and the due obedience law that exonerated middle- and low-ranking members of the armed forces. In 1990, Alfonsín's successor, the rightwing Peronist Carlos Menem, pardons those condemned at the junta trials.

This situation changed abruptly in 2003 when President Nestor Kirchner decided to support the nullification of the impunity laws in congress and therefore paved the way for the current truth trials that started in the following year. Affecting all the perpetrators - no matter their level of responsibility - the trials have resulted in more than 300 convictions to date.

The impact of contemporary approaches in these new trials is notable as regards gender issues. It is a fact that during the junta trials, these kinds of testimonies were sometimes heard but not considered in their specificity. ${ }^{18}$ Actually, when the victims started testifying on cases of gender violence - mainly, rapes - the judges usually stopped them, citing the need to protect the witness. This was certainly the general approach then taken by the judiciary: the strong belief that a testimony of rape, for example, somehow amounted to a second rape. It was as if the exposure of affects - understood in negative terms - could have contaminated the rationality of the judiciary. In addition, it was also as if the public sphere could be dramatically separated from the private realm.

As a matter of fact, even taking into account that crimes against sexual integrity were not included in the impunity laws passed between 1987 and 1989, for a number of years no such cases were heard by the judiciary. It was only after the derogation of these laws that the debate about this issue entered the public sphere.

For the purpose of this article, it is relevant to note that, in cases of sexual violence, the judiciary could only get involved at the request of the victim. On the other hand, the fundamental evidence needed to prove a crime against humanity is precisely the testimony of the victim. ${ }^{19}$ Therefore, this is a case where the relevance of testimonies is amplified, not only in terms of the role they play as proof, but also because an indictment can only be issued if the complainant wishes it. 
As it has been scrutinised from the perspective of traditional western feminism, all such crimes were committed under the patriarchal assumption of female subjection; women were considered subversive in two simultaneous senses: by questioning the social order through their activism, but also at defying the hegemonic gender stereotypes they were supposed to reproduce. ${ }^{20}$ It was mostly under torture that women suffered this double subjection to power: the one established between the oppressor and the oppressed and the one linked to gender hierarchy. ${ }^{21}$ Indeed, according to one of the victims, the favourite insult of a director of one of the detention centres for inmates was "bad mothers". After each act of torture, he would say: "Instead of taking care of your children, look where you are now."22 Women's participation in public issues itself was deemed subversive as was the use of violence as a political tool, a crime for which all the inmates were blamed. ${ }^{23}$

It is quite evident, then, that the traditional western feminist point of view is based on the double victimisation of female victims: as political activists and as women. A strategy based - again - on the sole role of the injury as a strategy to characterise a political actor. Notwithstanding my agreement with the existence of this double form of oppression, it is my view that this diagnosis is still based on a dichotomy of agency/victimhood that prevents the mere possibility of imagining emancipation. Is there an alternative way out of this dilemma? Can victims be agents and still victims? The answer, I argue, is in the debate prompted by the public exposure of pain.

The need to preserve women from being affected by a possible revictimisation through presenting testimony has been often emphasised. Weinstein, Negro and Llonto, for example, have analysed the treatment given to testifiers, describing them as passive victims of the judiciary: "How many times must a victim-witness render testimony on the same facts? How many follow-up questions about his/her suffering and his/her past must he or she endure? ... Full of expectations, anguish, preoccupations, prejudices, phobias and beliefs, our witnesses wander around the aisles of our courtrooms". ${ }^{4}$ I consider, on the contrary, that this perspective reaffirms the matrix under which submission has been legitimised. A matrix sustained in strict dichotomies, such as the ones that divide public and private realms, affects from reason, body from language, agency from victimhood, and individual and public memory.

As Segato has stated, sexual violence is usually interpreted as consistent with the intentions of the perpetrators: an act of obliteration of subjectivity ${ }^{25}$ that results in the empowerment of the perpetrators and the characterisation of the victims as essentially fragile. As I'll argue, the traditional way of interpreting the actual testimonies - based on a dychotomic feminist perspective that considers affects as passive - paradoxically follows this rule. It is time, then, to carefully listen to victims' metatestimonies, statements where they usually problematise the mere act of giving testimony, rejecting that kind of appropriation of their experiences.

It is not only what women say about their experiences that matters here: the presence of their bodies in the trials that express the pain suffered may also help to resignify the injury and empower the victim. If rape is considered a desubjetivisation of the victim, a reification, ${ }^{26}$ why is there such a resistance to see testimonies as strategies to empower agency? Isn't this reluctance a case of revictimisation, not through the act of giving testimony but when these depositions are interpreted as victimisations? 
What really concerns us here is that some recent analyses of the topic, regarding the current trials, are based on the same theoretical tools that sustained the 1985 perspective. It is in this respect that I consider it relevant to scrutinise one of the arguments that intends to sustain the perspective rejected by this article. Indeed, Elizabeth Jelin - a feminist academic - has argued that "in our current society, in which the mass media is engaged in a 'publicisation' of private life via talk shows and reality shows that trivialise feeling and intimacy, the risk is run that the testimonials fall into the trap of (excessive) exhibitionism and sensationalising the horrific."27

It is as if the only possible consequence of the exposure of affects was its reification. As if respecting the strict boundaries between the public and the private spheres was the best strategy to avoid the commercial use of suffering in the way the media does. As if, also, the affective dimension were to be blamed for desubjetivisation, instead of being a productive way of empowering agency. On the contrary, I believe that even affects considered negative - such as shame, as I'll analyse in the last section - may generate emancipatory results through their exhibition in the public sphere. Later in her argument, Jelin insists that: "The main characteristic of the Commissions of Truth and the trials is that they are centred on the category of 'victim' ... The focus on categories of victimisation needed to organise the mass of information that must be handled produces standardised and normalised narratives; it also produces the silencing of other experiences that do not fit the preestablished framework." 28

What is missing from Jelin's perspective is that in these trials, women not only play the role of victims but also - and essentially - of complainants, meaning subjects of law. ${ }^{29}$ It is thanks to their decision to denounce the crimes that many of these trials are taking place, a resolution that certainly challenges the dichotomy of agency/victimhood, which Jelin seems to cherish so much. The conclusions of Jelin's analysis are clear in this respect:

To overcome the void created by repression implies the possibility of elaborating a narrative memory of the experience, which is necessarily public in the sense that it must be shared and communicated to others ... In order to be able to speak out, one needs a space of confidence, a space where being listened to is central ... How is it possible to combine the need to build a public narrative and, at the same time, allow for a recovery of intimacy and privacy? ... [T]he pressure to talk is exerted on women whose subjectivity is torn between a desire to expose the body in intimate detail before a social gaze (which can turn to sensationalising the horrific) and the urgency to maintain or recuperate a humiliated intimacy, to be kept for themselves or shared with whomever they wish to do so, away from the cameras, away from the public gaze of mass exhibition. ${ }^{30}$

First, it is not a matter of getting privacy back, but to challenge its very definition. Second, and most importantly, Jelin forgets that testimonies are performative and, therefore, constitute the testifiers, as well as - at least partially - the scene and the rules of the trial.

This characteristic emerged as self-evident throughout the observations of the trials I made for the purposes of this investigation. In each case, the deponents who - in contrast to the junta trials - faced the accused parties, evidence through their own bodies the pain embedded in certain 
specific, key moments. Their recollections of facts - more frequently interrupted by bursts of crying and anguish than in the context of the description of other sorts of violence - lead to a radical transmutation of the scene. Few of those witnessing the declarations are capable of looking the deponents straight in the eye while listening to their testimony. However, after the initial moments, the gravity of testimony becomes much more radical and the listening much more attentive. It proves impossible to maintain staring at the deponents as the depositions develop, as from that moment all those involved in the trial - prosecutors, judges, witnesses, defendants - pay precise and direct attention to the deponent which helps her, even as she withholds her grief, to adopt a stand radically different to that at the beginning of her testimony. The general sense of shame that permeates the courtroom does not vanish, but its public exposition redefines the roles. Sheer victimisation is, in this way, challenged through the disruption of the common logic of the court, allowing for the introduction of alternate narrative strategies that go beyond the typical language used. Testimonies refer to the content of past experiences, but they are also deeply performative and it is through the exposure of affects that this performativy becomes effective. As Sedgwick has claimed, affect itself is performative and expresses "a radical estrangement between the meaning and the performance of any text". ${ }^{11}$ It is thanks to the presence of affects - and yes, of what is usually called "privacy" - that testimonies have powerful consequences in the public sphere. The presence of a torsion between reference and performativity, as characterised by Sedgwick, ${ }^{32}$ speaks of a queer performativity that combines the production of meaning and being. ${ }^{33}$ These torsions, or aberrances between reference and performativity, ${ }^{34}$ are unavoidable for Sedgwick, but particularly visible under the scope of affects. I consider that testimonies permeated by affects express this torsion, helping to offer information about the past and to constitute testifiers simultaneously as agents and as victims while transforming the scene of the trial. This estrangement between performativity and reference is not a mere overlapping of functions, but a dimension that deepens both aspects of language.

Paradoxically perhaps, but these features have helped transform the logic of the public sphere through the exposure of allegedly private affects. Affects that, in some way, are still intimate, but have burst into acting out their double bind: with performativity and with reference.

As a matter of fact, I believe that the main problem with Jelin's argument is that it is based on a dualistic perspective on agency ${ }^{35}$ - as a mere capacity of action opposed to the passiveness of victimhood - on a dichotomy between public and private spheres, on a limited idea of body (as an antonym to language) and on a conception of emotions as being merely individualistic and opposed to the allegedly rationality of the public sphere. It also supports a concept of trauma that is not attentive to some recent developments of the affective turn that have questioned - as I'll analyse in the next section - the shortcomings of such a strategy.

The accounts of rape, where the representation of the body is central, within the context of these trials show, I argue, that trauma that is publicly exposed does not necessarily victimise - as it does happen in other contexts - but can further empower the victim's agency and also establish an alternative collective and agentic bond with the said past. The traditional dichotomy between an active and a passive pole is here called into question. It is in this context that, for example, the judicial decision - initiated by the verdicts of judges Bajes and Bailaque - to consider gender vio- 
lence produced in this context as cases of crimes against humanity, introduces a new perspective on this matter. The testimonies of these crimes given by victims themselves assume that trauma when publicly exposed does not necessarily victimise - as it actually happens in certain contexts but may even deepen the victim's agency and establish an alternative collective link with the past. As Margarita Cruz said in her metatestimony: "No one asked me anything on my way out. No one was asked about anything. Not even my family, to this day, asked me about what had happened. Nor could that be said in the context of political militancy. I think that the true victimisation is not to ask." As I shall see in the next section, many other victims have insisted on these agentic qualities of giving testimony.

\section{Metatestimonies as queering tools}

"I spent 30 years of my life trying to forget and now I am asked to remember ... I became myself again when I started collaborating in the reconstruction of the crimes I suffered. ${ }^{36}$ These two sentences from Ana María Careaga - a former desaparecida or "disappeared" - reminds us of a tension evoked by many victims: the certainty that their traumas will never be overcome and the appreciation of the role of testimony as a subjective restitution.

"There's always something irreparable," says Careaga. ${ }^{37}$ There is pain involved both in suffering the crimes and in telling the stories, but also the belief that the scene settled by the judiciary - partially through testimonies themselves - can repair some of the consequences of state terrorism. As Careaga admits: "It helps to include history in a collective dimension. Juridical sanction relieves pain." ${ }^{38}$

This section is devoted precisely to what I call metatestimonies, meaning testimonies given by victims about the act of giving testimony itself. In order to assess the analyses that have insisted on the revictimising nature of these testimonies, it is now time to consider what the victims have to say. Actually, it is thanks to the public exposure of pain that these testimonies manage to challenge such dichotomies: it is through affects that the distinction between the public and private sphere is challenged, as well as the strict difference between agency and victimhood. The expression of anger, guilt, pride, shame or fear defines the performativity of testimonies that helped to empower them without essentialising their identities. Here, the exceptional qualities of affects to challenge binarisms and to rebuild the logics of the public through their contingency are expressed in all its consequences.

The pain and the shame of testifying are of course always present in metatestimonies. As Norma Bert said in 2007: "I must admit that I have a limitation, which is that I cannot bear any talk about this thing - torture - ... I think that speaking about the experiences of the body is one of the most difficult things in life ... it is very difficult to talk about pain, I mean about physical pain." ${ }^{39}$

In her words, the involvement of the body plays a substantial, double role: it refers to her suffering at being raped but also at reconstructing the crimes publicly. Body and language are here equally performative. In this respect, it should be remembered that under traumatic experiences, "the body becomes a memorial",40 meaning that it becomes a reservoir of the past. However, a memorial is 
not just a condensation of the past but also an act in the present that imposes its own performative force in the public arena. "You will never be able to communicate the dimension of what happened. Never. Even when you speak about it every single day of your life, you would never be able to communicate the dimension of it. What it does to you, you would never be able to transmit. It is as if this has torn you in two. ${ }^{41}$

This anonymous metatestimony refers to the undisputed limits of trauma. This dimension is not something I pretend doesn't exist; on the contrary, instead of debilitating it I formulate it from a perspective that may help to introduce testimony as empowering agency. Actually, the notion of trauma has been used to argue that having suffered such crimes, victims are left paralysed and incapable of distinguishing past from present.

The nature of trauma is clearly exposed by one of the victims: "after being raped it was as if my body was frozen, as if it belonged to someone else, as if I had no sensations at all". ${ }^{42} \mathrm{~A}$ lack of sensation, alienation and freezing are among the main attributes of trauma.

It is particularly relevant to remember that the debate about the role of trauma was developed with Caruth's and Leys' work, a perspective that pays special attention to its effects on the ego..$^{43} \mathrm{Ob}$ jections against the use of the concept of trauma to explain events such as genocide are focused on the potential disempowerment of trauma itself and the dissolution of any narrative: "trauma is forgetting without memory, so that traumatic effects are a symptomology substituting for what was never experienced as such". ${ }^{44}$ One of the characteristics of trauma is what it does to the ego. In Leys' words, "it is drawn back into the ego. There is a coalescence of the ego with the object or event of fascination. Trauma is the engulfment of the ego in memory". ${ }^{45}$ Even accepting this challenging description, I find it essential to stress that exposing trauma does not dissolve its qualities, but establishes its consequences precisely beyond the ego. Not only does it imply the recognition of "transgeneraltional haunting" - meaning haunting across different generations ${ }^{46}$ but also that the "entanglement" of a ghosted body ${ }^{47}$ when publicly exposed may establish a kind of "communal haunting" that helps to overcome the narcissism of traumatic experiences and, therefore, to distinguish past from present.

As I have previously established, trauma studies are being currently scrutinised under the affective turn providing an alternative approach to the role of the witness/victim of traumatic events. ${ }^{48}$ In considering trauma as a performative affect - instead of focusing exclusively on its paralysing logic - these testimonies are there to be grasped as empowering without erasing victimhood. Even melancholy ${ }^{49}$ and depression ${ }^{50}$ can be analysed in their positive dimensions: it is not just a matter of engulfment but also of an empowering ambiguity ${ }^{51}$ capable of generating creative movements, or rather the core of agency.

What the affective turn has discussed is that the involvement of affects implies a breakup of the distinction between a passive and an active pole: suffering no longer implies sole passiveness nor exclusive engulfment. It is in this respect that Sedgwick's appreciation regarding the sense of touch becomes useful: "the sense of touch makes nonsense out of any dualistic understanding of agency and passivity; to touch is always already to reach out, to fondle, to heft, to tap, or to enfold, 
and always also to understand other people or natural forces as having effectually done so before oneself, if only in the making of the textured object." ${ }^{\text {"2 }}$

Trauma also fondles, hefts, taps, enfolds, making its nature appear as ambiguous. Thinking trauma as a chaotic experience - which it is - does not imply considering it a mere dissolution, but rather a complex opportunity to redefine agency.

As Ahmed has stressed: "a good scar is one that sticks out, a lumpy sign on the skin. It is not that the wound is exposed or that the skin is bleeding. But the scar is a sign of the injury: a good scar allows healing, it even covers over, but the covering always exposes the injury, reminding us of how it shapes the body." ${ }^{.53}$

It is here where testimonies permeated by "emotions become the very flesh of time" ${ }^{54}$ The healing nature of testimony becomes clear in Alicia Morales' metatestimony:

For too long we've tried to erase our memory so that no one else would have to suffer what we were suffering ... They used to tell me: "Don't remember; it only hurts you". At the beginning I used to think: "Why would it be harmful to me if I want this to be known?" And later on, I realised that what happened was that it was indeed painful to the listener, because what was told made the listener take sides, to be aware, right? And no one wanted to be aware. And so it took 30 years, for example, for us to be able to talk about certain things..$^{55}$

On the one hand, Alicia reminds us that the assumption that silence about suffering is better than exposing it is just a sophisticated way of describing the resistance of bystanders to know what happened. On the other, she is emphasising that testifying may be liberating, but only under specific circumstances.

In this respect, Marta Alvarez's words are particularly clear: "During the junta trials, there were testimonies about rape, but they were considered cases of torture; I think today there's another way of listening; you can be listened to differently, as in society there is another way of listening about violence and mistreatment." ${ }^{\text {"56 }}$

The most substantial contribution of metatestimonies - at least from the point of view of this article - is related to the empowerment of these women. One of them said: "First you want to forget, but later one strives to remember. I wanted to work out why I was called tortillera [dyke]" ${ }^{57}$ The nature of the insult, the origin of a scar, will never be worked out, but through public exposure the victim can be placed into a matrix of meaning capable of erasing the disempowering nature of trauma. Since affects are present not only in their testimonies but also in their metatestimonies, healing does not imply "solving" anymore, as knowing does not mean certainty.

The fact that women narrate these stories has been sometimes related to vulnerability. ${ }^{58} \mathrm{How}-$ ever, it is my view that the exposure of vulnerability is actually a way to empower agency. Indeed, vulnerability and mourning prompt the questioning of the constitution of identity as an horizon from where to sustain political agency and, with it, the emancipation under alternative premis- 
es. Let us briefly reconstruct the concepts relative to this point. Butler mainly highlights vulnerability as a basis for a community. ${ }^{59}$ In her own words, this implies that "grief displays the thrall in which our relations with others hold us, in ways that we cannot always recount or explain".60 She argues that "the skin and the flesh expose us to the gaze of others, but also to touch, and to violence, and bodies put us at risk of becoming the agency and the instrument of all these as well ... the very bodies for which we struggle are not quite ever only our own. The body has its invariably public dimension."61

In other words, far from impeding empowerment, instabilities established by the imprints of disruptive events on the present are, on the contrary, generating new meanings: opening it to the public implies the constitution of a space for agency. Under the scope of the affective turn, this conclusion prompts the conviction that vulnerability is a case of admitting the presence of affects. There is a need to expose the facts, to put them into words. "It's liberating, completely liberating. Justice and reparation start when you can testify, when the conditions to testified are given",62 says one of the victims. Actually, it is not just what women say that matters here - even considering the performative force of testimonies - but also what they do: by choosing to become complainants, they decide to expose their suffering through action.

These paradoxical characteristics of agency are used by one of the victims, in a pristine way, to evoke her difficulties while trying to conceptualise her suffering. CG says: "In democratic times, tales of heroism was the usual narrative; I felt I was not a hero and this made me feel guilty. I felt ashamed". ${ }^{63}$ This suggests that the traditional strategy to survive in the camps - and immediately afterwards - was to envisage themselves as heroes, as if the answer to victimhood were pure agency. ${ }^{64} \mathrm{Her}$ reluctance to conceptualise her experience from this heroic perspective resulted in guilt and shame: guilt at not being able to overcome her status as a victim through heroism, in other words strict agency, and shame for not being what others expected her to be.

I consider that this metatestimony shows us the complex nature of the tension between agency and victimhood - CG does not want to be seen as a mere victim, but neither does she wish to be viewed as a hero - as well as the essential role played by what are called "negative feelings", which are, as I'll scrutinise in the following section, the ones that divert us from pleasure. Paradoxically then, perhaps, it is the rebellion against stereotypes that sometimes prompted these women to testify. As Margarita Cruz, one of the first survivors to give testimony about sexual crimes in the context of the National Commission on the Disappearance of Persons (Conadep) in 1984, said: "My body began to reconstitute itself when, 15 years after the facts, I saw myself giving testimony about the sexual violence I suffered on a recording where I was clearly victimised because it was never mentioned that I was a political militant. But it was the actual viewing of these images which started to change everything. I am both persons."

\section{Twisting affects: shame and beyond}

Our case study of the metatestimonies given by former female disappeared-detainees during the current trials for crimes against humanity in Argentina shows the importance of paying attention 
to the affective dimension of agency. Rescuing agency from any dualism means problematising the distinction between inner and outer spaces, between active and passive nodes.

In fact, the ideas developed by feminism on the issue of passion (Nussbaum, Mendus, Mouffe, Prokhovnik) have been discussed in the last few years in terms of affects, in other words, as an instance - as it has been introduced thorough this article - where the distinction between passion and reason is dissolved, where body and mind are thought as a unity. Braidotti's Deleuzian ideas and Gatens' Spinozian thoughts represent an inaugural attempt to debate this topic without reverting to humanism. ${ }^{65} \mathrm{Hardt}$ highlights that "affects refer equally to the body and the mind; they involve both reason and the passions". ${ }^{66}$ He later stresses that "the perspective of the affects, in short, forces us constantly to pose the problem of the relationship between mind and body with the assumption that their powers constantly correspond in some way". ${ }^{67}$ He goes on to say: "affects can be actions, that is, determined by internal causes, or passions, determined by external causes. On the one side we have reasons, actions of the mind, along with actions of the body, which one might call provocatively corporeal reasons; on the other side are the passions both of the mind and the body. ${ }^{.68}$

Affects - unlike drives not related with an object - "enable both insatiability and extreme lability, fickleness and finickiness". ${ }^{69}$ An affect is, actually, a collision between mind and body. ${ }^{70}$ Clough, who rejects viewing affects as presocial, ${ }^{71}$ adds: "affect refers generally to bodily capacities to affect and be affected or the augmentation or diminution of a body's capacity to act, to engage, and to connect". Indeed, affects act. ${ }^{72}$

On the other hand, one of the most important characteristics of affects when studied from this perspective is their capacity to articulate experience. According to Ahmed's description: "Affect is what sticks, or what sustains or preserves the connection between ideas, values, and objects". ${ }^{73}$ Ahmed herself, on the other hand, has dramatically insisted on the sociality of emotions ${ }^{74}$ Let me quote her extensively: "emotions should not be regarded as psychological states, but as social and cultural practices". ${ }^{75}$ Emotions are not "in" either the individual or the social, "but produce the very surfaces and boundaries that allow the individual and the social to be delineated. The objects of emotion take shape as effects of circulation". ${ }^{76}$ It is the objects of affects what circulate. "Such objects become sticky, or saturated with affects, as sites of personal and social tension."77

Social, unstable, dynamic and paradoxical, affects turn out to be powerful tools in order to reassess pre-existing - and comforting - definitions, particularly those linked to subjectivity, such as the one expressed in testimonies. ${ }^{78}$

I then sustain the thesis that this is an appropriate matrix to discuss the reformulation of agency under a paradigm related to affects, especially trauma resulting from crimes against humanity. The incorporation of the affective dimension can support, in a transformed manner, a conception of agency and the reformulation of ideas such as victimisation and trauma. Testimonies presented in terms that assess trauma as a productive affective dimension can empower agency, rather than victimising, thanks to alternative narrative strategies. Actually - and this is quite relevant for my purposes - it is not just a matter of believing as an academic that this paradigm is enriching, 
but that through metatestimonies victims themselves have introduced affects in a manner consistent with this framework, showing how empowering vulnerability can be. And, as "pain involves the sociality of bodily surfaces that 'surface' in relationship to others", ${ }^{79}$ vulnerability - far from being cloistered in intimacy - establishes its own principle of the social bond.

What kinds of affects are involved here? What are the effects of these particular affects? I'm clearly dealing here with some affects usually considered negative: shame, guilt, anger; all of which are assessed as bad, meaning - from a traditional point of view - that they are paradoxically ineffective at protecting us from negative feelings. ${ }^{80}$ As Ahmed has pinpointed: "While good feelings are considered progressive and forward, bad feelings are backward and conservative," ${ }^{\prime 1}$ as if actions could be boosted by feelings such as happiness and discouraged through, for example, hate or guilt. According to Ngai, who has looked at the notion of ugly feelings as being close to the notion of negative feelings, it is particularly relevant to give an account of the "negative affects that read the predicaments posed by a general state of obstructed agency with respect to other human actors or to the social as such." ${ }^{82}$ She later stresses:

Like rage and fear, ugly feelings such as envy can be described as dysphoric or experientially negative ... in the sense that they are saturated with socially stigmatising meanings and values (such as the "pettiness" one traditionally associates with envy); and as "syntactically" negative, in the sense that they are organised by trajectories of repulsion rather than attraction, by phobic strivings. ${ }^{83}$

It's important to see that Ngai wants to recover the critical productivity of these affects that are considered ugly or usually rejected, without romanticising them. ${ }^{84}$

In fact, one of the key affects involved in the metatestimonies herein analysed is shame. As Valeria del Mar Ramírez, the first trans person to testify regarding these crimes, said: "The first time I gave testimony, I could not hold myself together as I recalled the facts. I had to give a second testimony because the first time I was too ashamed. I could never deal with shame, but I went back because I wanted to tell everything in order to be able to be a plaintiff in these trials ... I was ashamed to talk about what had happened. After I gave testimony for the first time and actually realised the dimension of what had happened, it took me the best part of ten years to make the decision to file a criminal complaint. I could not help thinking, however, how good it would be if other girls felt encouraged to speak." For her, the persistence of shame does not overshadow the need to actively participate in the judicial process.

Traditionally, shame has been used as a justification to support the standard perspective on this matter: allegedly, in order to avoid the discomfort of victims, testimonies should be prevented or, at least, discouraged. I claim here that a careful analysis of shame from the perspective of the affective turn - where affects are considered as above - may help to comprehend its productive political consequences.

In this respect, it is important to reconstruct Sedgwick's argument around the topic. Defined by her as a protoaffect, shame is here considered as "a disruptive moment, in a circuit of identity-consti- 
tuting identificatory communication. Like stigma, shame is a form of communication ... It derives from and aims toward sociability ... Shame points and projects ... Shame is performance". ${ }^{55}$ Sedgwick's insistence on the liminal qualities of shame leads her to affirm that "shame is the affect that mantles the threshold between introversion and extroversion, between absorption and theatricality" ${ }^{86}$ Shame is here particularly relevant at analysing the way victims tackle their past suffering: ${ }^{87}$ as a mixture of uncanny monstrosity, erotisation and repudiation that results in a complex link to the past. Exposing shame is, for Sedgwick, "a strategy for dramatising and integrating shame, in the sense of rendering this potentially paralysing affect narratively, emotionally, and performatively productive" ${ }^{88}$ The tension between absorption and theatricality will always be there, but shame itself turns out to be a complex tool in order to define identity beyond any essentialism. After all, for her shame "generates and legitimates the place of identity - the question of identity is at the origin of the impulse to the performative, but does so without giving that identity space the standing of an essence. It constitutes it as to-be-constituted, which is also to say, as already there for the (necessary, productive) misconstrual and misrecognition." ${ }^{89}$

As one of the testifiers admitted: "The story is part of my scars. My daughter was listening in the courtroom. My daughter, my comrades, my family. It was difficult to evoke, very difficult. I felt ashamed because I knew that in that precise moment the pain was being transferred to my family."90

Shame thus plays a role at exposing the story that helps to define her scars, but also at denying the possibility of a comforting road to pride.

Indeed, Sedgwick is deeply critical of "the therapeutic or political strategies aimed directly at getting rid of individual or group shame". ${ }^{11}$ Thus, it is not a matter of simplistically transforming shame into pride as an emancipatory mechanism. Shame is here contagious and capable of boosting a highly politicised chain reaction of shame dynamics. Indeed, for certain queer people shame is the first, and permanent, structuring fact of identity. "Shame is where the sense of self is". ${ }^{2}$ Therefore, it is not a matter of overcoming shame in order to be empowered, but to performatively expose it.

Shame is defined by Probyn as an affect "that crosses many different orders of bodies", ${ }^{93}$ making it fully contagious ${ }^{94}$ For her - as for Sedgwick - "ideas and writing about shame seek to generate new ways of thinking about how we are related to history and how we wish to live in the present". 95 Shame is thus considered a free radical.

Probyn's and Sedgwick's approaches are essential to support my argument. If shame constitutes identity performatively and emancipation does not have to be understood as the replacement of shame by pride, then agency is not contradictory to victimhood. Moreover, shame becomes a central affect in order to establish a movement from intimacy to the public for erasing the strict limits between these poles, thus helping us to define an empowered identity in a field defined by ambiguities. As it has been established by Ahmed: "pain - probably, the origin of victim's shame - implies the attribution of meaning through experience. ${ }^{96}$ Although the politicisation of grief and the transformation of mourning into militancy show the way in which collective mourning has been 
transformed into action, as analysed by Cvetkovich and Gould in their assessment of the political action deployed during the first years of the Aids epidemic, ${ }^{97}$ it is important to stress - again - that this is not a matter of overcoming shame through pride, but of empowering agency without erasing shame. What becomes relevant here is the role played by shame in the constitution of nonessentialised identities. ${ }^{98}$

Is shame always an affect involved in emancipatory politics? Of course not. Actually, the analysis of the broad impact of shame at establishing a social bond may be a good example of the fulfilment of Ngai's mantra "not to romanticise it".

In this respect, it is important to look into the way shame not only helps to performatively define the role of victims but also that of the bystanders, which is difficult to grasp. Shame may turn out to be an affect that performs not the empowerment of the victim but the liberation of bystander's responsibility through their empowerment. As it has been noted previously, since shame "is a call for action and a demand for collective politics", ${ }^{\prime 9}$ it is also an affect that broadly permeates the social bond. After suffering genocides or crimes against humanity, societies tend to evade their responsibility in terms of shame. As Ahmed has pinpointed: from the point of view of bystanders national shame replaces individual guilt ${ }^{100}$ and becomes not only a recognition of injustices but also a form of nation building. Therefore, shame may not only be performative from an emancipatory, but also from a conservative, point of view. Its effects go beyond the victim's symbolic compensation to involve a complex and paradoxical link with the community involved.

One testifier, M7, said: "When I started talking in the courtroom, the defendants were grey. They looked away all the time. Four of them were guards. At some point, I could no longer stand this situation, so I fainted." "101 Here, the collision of different versions of shame is what creates a paradoxical but real bond. It is also a moment when the expression of shame by the perpetrators helps them to evade their responsibility.

What's important here is to emphasise that reassessing the critical dimension of ugly or negative affects does not imply - as mentioned above - romanticising them. The impact of the stickiness of shame on bystanders is then a useful example of the broad and pluralistic consequences of paying attention to the performative force of testimonies.

Miriam Lewin - one of the testifiers at the trials - has evoked how, while she was a desaparecida, she and other inmates were taken to fancy restaurants as officer's escorts. Though terrified, they never refused to go. They even smiled at their torturers. However, as an act of resistance they always ordered the most expensive dish on the menu. In that moment of deep terror, they knew they could take some apparently irrelevant decisions to escape the labelling of being pure victims. Testifying about this story, expressing the affects involved, choosing the right words and the moment to reveal it was more than an act of resistance; it was an example of how the complex nature of feelings may offer an alternative view of agency.

Having discussed the way in which the role of the testimony of victims of sexual crimes against humanity provides an opportunity to debate the tension behind victimhood and agency, I argue that it 
is thanks to the exposure of affects that the performative dimension of testimonies arises, erasing traces of an essentialising conception of victimhood. Thus, under the umbrella of the recent recovery of the affective dimension, I have shown the way in which "agency" should be transformed beyond the dichotomies of agency and victimhood, but also private and public and reason and affects.

Assessing the manner in which the testimonies of cases of sexual violence defined as crimes against humanity can empower agency rather than plunge it into victimisation has become a laboratory to discuss a traditional feminist topic from a different perspective. It is also a way to assess strategies devoted to developing politics of memory beyond the dangers of disempowering victims and an example of the role that the affective turn may play in contemporary philosophy of history. If it is considered that feeling bad - guilt, despair, shame, depression, trauma, envy - can become the starting point of political action, dealing with the injured past will never be a road to revictimisation. Agency is not a matter of overcoming these affects but of focusing on their creative qualities, capable of deploying an exceptional political potential. ${ }^{102}$ It is not just a matter of remembering that "traumatic experiences of rejection and humiliation are connected to identity formations", 103 but also of expelling the idea of the passive and private nature of suffering. ${ }^{104}$

\section{NOTES}

* $\quad$ First of all, I would like to thank the bravery and extreme hospitability of all the persons interviewed for this research. I would also like to thank Mariela Solana, who read many versions of this paper and proposed important changes; and Diana Maffía, Marta Vasallo, Cecilia Sosa, Valentina Salvi, Daniela Losiggio, Irene Depetris Chauvin, Alejandra Dandan, Valeria Canal, Sam Ferguson and Fernando Gorbea for their help in writing this article: being commenting, reading, suggesting strategies or just chatting. The feedback from audiences at the Ghent conference on The Future of the Theory and Philosophy of History (10-13 July 2013), organised by the International Network for Theory of History, and I Simposio Pensar los Afectos (Buenos Aires) helped to improve this paper. The generosity of Pothiti Hantzaroula made the publication of this article possible.

1 Marta Vasallo (ed.), Grietas en el silencio, Cordoba: Cladem-Insgenar, 2011, 29.

2 In this article I use the word "victimhood" to refer to the quality of being a victim. "Victimisation", on the other hand, gives account of the process of becoming a victim.

3 Alejandra Dandan, “'El cura sabía que era una secuestrada'”, Página 12 (5 October 2011), 8.

4 Mariana Carbajal, “Una atrocidad sin límites”, Página 12 (4 July 2011), 10.

5 I should clarify that by sexual violence, we mean not only rape but also verbal violence, threats of sexual abuse, forced nudity, unwanted pregnancies as a result of rape, forced abortions, miscarriages due to torture, abduction of babies (mostly born in illegal detention centres), sexual slavery, torture performed on the genitals, lack of intimacy and the usual practice of forcing women to give birth in inhuman conditions. Susana Bilbao, "Análisis crítico de la violencia sexual y la violencia de género durante la última dictadura militar (1976-1982) y construcción de significaciones vinculadas al género en los juicios de la actualidad", 2010, 6 (available at perio.unlp.edu.ar/ojs/index.php/question/article/viewFile/1228/1091, accessed 7 April 2014). 
6 By "metatestimonies", I'm referring to what the victims express as their own affective experiences on the fact of giving testimony, primarily through their own words, but also through their bodies and actions. I am aware of the fact that part of such experience is not properly captured by language. However, we concur with Stephen Pile in that, even when such awareness is necessary, the more productive methodological path is to profit from a multiplicity of sources without assuming the radical opacity of affects. This implies resorting to elements such as gestures or the way in which affects reflect into actions, but also to what the deponents say about their own experiences. Thus, we use not only primary sources - interviews made specifically for purposes of this work - but also secondary material included in various writings of diverse origin where the affective issue is not a central part of the analysis. The fact that affects - characterised as fluid and unstable - cannot be entirely represented does not imply that we should avoid referring to them, much less to assume a radically distortive nature in the words of victims. See Stephen Pile, "Emotions and Affect in Recent Human Geography", in Transactions 35 (2009), 5-120.

7 Through this paper, unless stated otherwise, I use the notions "affect" and "emotion" as synonyms. I am aware of the important distinction between affects as a prelinguistic, unstructured and allegedly authentic dimension, and emotions as cultural and linguistic expressions of affects. However, since my approach is based on what victims said about their experiences, but also on capturing the embodied nature of metatestimonies - through observations and a registry of extralinguistic expressions - I prefer to maintain the ambiguity of the tension between both concepts. I have developed a criticism of this distinction in my "Sentimus ergo sumus: el surgimiento del 'giro afectivo' y su impacto sobre la filosofía política”, in Revista Latinoamericana de Filosofía Política 2/6 (2013): 1-32.

8 In "Sentimus ergo sumus", I have extensively argued against the perspective that finds in affects an authentic and naturally empancipatory space. For a critique of these romantic consequences, see Clare Hemmings, "Invoking affect: cultural theory and the ontological turn", Cultural Studies 19/5 (2005): 548 -567 .

9 Wendy Brown, States of Injury, Princeton: Princeton University Press, 1995.

10 Ibid.

11 After the end of the dictatorship, and particularly since 2003, Argentina suffered important changes as regards gender issues. The bill legalising divorce (1985), the electoral quotas law (1991), the sexual education law (2006), the law against sexual exploitation (2008), the same-sex marriage law (2010) and the gender identity law (2012) show the political relevance of the debates around these topics and their impact on everyday life. Simultaneously, the local development of feminist theory offered a sophisticated framework for these discussions and for others still unresolved, such as abortion legalisation.

12 Sianne Ngai, Ugly Feelings, Cambridge: Harvard University Press, 2007.

13 Michael Hardt, "Foreword: What affects are good for", in Patricia Ticineto Clough and Jean Halley (eds), The Affective Turn, London: Duke University Press, 2007, 50-53.

14 Sara Ahmed, The Cultural Politics of Emotion, London: Routledge, 2004, 32.

15 Brown, States of Injury, 55.

16 Ahmed, The Cultural Politics of Emotion, 32.

$17 \quad$ Ibid, 33.

18 V.AA, Y nadie quería saber: Relatos sobre violencia contra las mujeres en el terrorismo de Estado en Argentina, Buenos Aires: Memoria Abierta, 2012, 5 
19 María Sondereguer and Violeta Correa (eds), Violencia de género en el terrorismo de estado: políticas de memoria, justicia y reparación, Bernal: Universidad Nacional de Quilmes, 2010, 44.

20 VV.AA, Y nadie quería saber, 95.

$21 \quad$ Ibid, 49.

22 Vasallo, Grietas en el silencio, 33.

23 It is important to note that around $5-10 \%$ of the cases of sexual violence were performed against men. However, no male victim has testified so far.

24 Marcos Weinstein, Liliana Nigro and Pablo Llonto, “'¿Cuántas preguntas deben soportar?'”, Página 12 (12 January 2012).

25 Rita Segato, Las estructuras elementales de la violencia, Bernal: Universidad Nacional de Quilmes, $2003,13$.

26 Vasallo, Grietas en el silencio, 66.

27 Elizabeth Jelin, "Sexual abuse as a crime against humanity and the right to privacy", Journal of Latin American Cultural Studies 21/2 (2012): 343-350, here 348.

28 Ibid, 346.

29 VV.AA, Y nadie quería saber, 10. It is also relevant to highlight that, in prior writings, Jelin has recognised that in such contexts, victims, when acting as plaintiffs, become legal subjects. Elizabeth Jelin, "¿Víctimas, familiars o ciudadano/as? Las luchas por la legitimidad de la palabra", in Emilio Crenzel (ed.), Los desaparecidos en la Argentina: Memorias, representaciones e ideas, 1983-2008, Buenos Aires: Biblos, 2010, 236.

30 Jelin, "Sexual abuse", 348.

31 Eve Kosofsky Sedgwick, Touching Feelings, Durham: Duke University Press, 2003, 7.

32 Ibid.

33 Ibid, 61

34 Ibid, 62

35 In "Giro afectivo y reparación testimonial: el caso de la violencia sexual en los juicios por crímenes de lesa humanidad" (Mora, forthcoming), I have compared Jelin's dualism with the one deployed by Scarry's classical analysis of torture.

36 Ana María Careaga, “Testigos necesarios”, Página 12 (12 January 2012), 22.

$37 \quad$ lbid.

38 Ibid.

39 VV.AA, Y nadie quería saber, 85.

40 Patricia Ticineto Clough (ed.), The Affective Turn, London and Durham: Duke University Press, 2007, $178-81$.

41 V.AA, Y nadie quería saber, 90.

42 Vasallo, Grietas en el silencio, 97.

43 Cathy Caruth, Unclaimed Experience, Baltimore: John Hopkins University Press, 1996; Ruth Leys, 
“Death masks: Kardiner and Ferenczi on psychic trauma”, Representations 53 (1996): 44-73, here 54.

44 Clough, The Affective Turn, 171-74.

45 Leys, “Death masks", 54.

46 Clough, The Affective Turn, 183-86.

47 Ibid, 186-88.

48 Ruth Leys, From Guilt to Shame: Auschwitz and After, Princeton: Princeton University Press, 2007.

49 Jonathan Flatley, Affective Mapping: Melancholia and the Politics of Modernism, Cambridge: Harvard University Press, 2008, 22.

50 Ann Cvetcovich, Depression: A Public Feeling, London and Durham: Duke University Press, 2012, 21.

51 Heather Love, Feeling Backward: Loss and the Politics of Queer History, Cambridge: Harvard University Press, 2007, 150.

52 Sedgwick, Touching Feelings, 14.

53 Ahmed, The Cultural Politics of Emotion, 201-202.

54 Ibid, 222.

55 VV.AA, Y nadie quería saber, 88.

56 Alejandra Dandan, "Al fin, justicia”, Página 12 (23 January 2011), 18.

57 Vasallo, Grietas en el silencio, 96.

58 Ibid, 242.

59 Judith Butler, Precarious Life, London: Verso, 2004.

60 Ibid, 23.

61 Ibid, 26.

62 Vasallo, Grietas en el silencio, 294.

63 VV.AA, Y nadie quería saber, 86.

64 This point of view is consistent with the counter-heroic logic developed by Athanasiou in terms of critical or spectral agency. See Athena Athanasiou, "'Who is that name?' Subjects of gender and queer resistance, or the desire to contest", European Journal of English Studies 16/3 (2012): 199-213.

65 Melissa Gregg and Gregory Seigworth, "An inventory of simmers", in Melissa Gregg and Gregory Seigworth (eds), The Affect Theory Reader, Durham and London: Duke University Press, 2010, 15.

66 Hardt, "Foreword: What affects are good for", 34-37).

67 Ibid, 43-44, 46-49.

68 Ibid, 49-52.

69 Sedgwick, Touching Feelings, 52.

70 Elspeth Probyn, "Writing shame", in Melissa Gregg and Gregory Seigworth (eds), The Affect Theory Reader, Durham: Duke University Press, 2010, 80.

71 Clough, The Affective Turn, 106-109. 
Gregg and Seigworth, "An inventory", 2.

73 Sara Ahmed, "Happy objects”, in Gregg and Seigworth, The Affect Theory Reader, 29.

74 Ibid, 8.

75 Ibid, 9.

76 Ibid, 10.

$77 \quad$ lbid, 11.

78 It is important to stress that this paper does not sustain a romantic conception of affects based on the allegation that this dimension is emancipatory by nature. Actually, affects can sometimes reaffirm oppression or legitimate segregation. For a critical approach of these dangers, see Clare Hemmings, Why Stories Matter, Durham: Duke University Press, 2011.

79 Ahmed, The Cultural Politics of Emotion, 31.

80 Sedgwick, Touching Feelings, 134.

81 Ahmed, "Happy objects", 50.

82 Ngai, Ugly Feelings, 3.

83 Ibid, 11.

84 Ibid, 4.

85 Sedgwick, Touching Feelings, 36-37.

86 Ibid, 38.

87 Ibid, 40.

$88 \mathrm{Ibid}, 44$. The theatrical qualities of shame have also been studied by Jacqueline Rose, On Not Being Able To Sleep: Psychoanalysis and the Modern World, Princeton: Princeton University Press, 2003. In her own words: "Shame may require an audience, but at the same time it is secret and hidden, not something which as a rule people are in a hurry to share ... Contrary to guilt, which could easily ulcer within yourself, shame only surfaces when someone knows or is afraid to be looked at" (Kindle location, 109).

89 Sedgwick, Touching Feelings, 64.

90 Vasallo, Grietas en el silencio, 298.

91 Sedgwick, Touching Feelings, 62.

92 Ibid, 98

93 Probyn, "Writing shame", 82.

$94 \quad$ Ibid, 88.

95 Ibid, 89.

96 Ahmed, The Cultural Politics of Emotion, 23.

97 Ann Cvetkovich, An Archive of Feelings, Durham: Duke University Press, 2003, and Deborah Gould, Moving Politics, Chicago and London: University of Chicago Press, 2009.

98 Sedgwick, Touching Feelings, 64. 
99 Ahmed, The Cultural Politics of Emotion, 39.

100 Ibid, 102.

101 Vasallo, Grietas en el silencio, 303.

102 Love, Feeling Backward, 154.

103 Cvetkovich, An Archive of Feelings, 47.

104 Love, Feeling Backward, 150. 